\title{
İmmünsüpresif Tedavi Alacak Hastalarda Hepatit Serolojisi
}

\section{Hepatitis Serology in Patients Receiving Immunosuppressive Treatment}

\author{
Mehmet CABALAK $^{1}{ }^{(D)}$, Tayibe BAL ${ }^{1}$ (D) , Sabahattin OCAK ${ }^{1}$ (D)
}

1 Hatay Mustafa Kemal Üniversitesi, Tayfur Ata Sökmen Tıp Fakültesi, Enfeksiyon Hastalıkları Anabilim Dalı, Hatay, Türkiye

Öz.

Amaç: İmmünsupresif ilaç kullananlarda, hepatit B reaktivasyon riskine yönelik tarama yapılması önerilmektedir. Bu çalışmada immünsüpresif tedavi öncesi, Enfeksiyon hastalıkları kliniğine yönlendirilen hastalarda hepatit $B$ virüsü (HBV), hepatit $C$ virüsü $(\mathrm{HCV})$ ve hepatit $A$ virüsü (HAV) sonuçları retrospektif olarak irdelenmesi amaçlandı.

Materyal ve Metod: Çalışmamızda Ocak 2018 - Aralık 2018 tarihleri arasında immünsüpresif tedavi öncesi, Enfeksiyon hastalıkları kliniğine yönlendirilen 148 hastanın hepatit B yüzey antijeni ( $\mathrm{HBsAg})$, hepatit B yüzey antikoru (Anti-HBs), hepatit B core protein antikoru (Anti-HBc lgG), anti hepatit C virüs antikoru (Anti-HCV) ve anti hepatit A virüs antikoru (Anti-HAV) hasta dosyalarından ve hastane otomasyon sisteminden retrospektif olarak incelendi.

Bulgular: HBsAg pozitiflik oranı \%4,1, Anti-HBs pozitiflik oranı $\% 31,8$, İole Anti-HBc lgG pozitiflik oranı $\% 1,4$ ve iki hastada ise Anti-HBs bakılmamıştı. Anti-HCV pozitifliği \%1,4 tespit edildi. Hastaların \%79,7 Anti-HAV bakılmamış, Anti-HAV pozitifliği \%12,2 ve Anti-HAV negatifliği \%8,1 olarak saptandı.

Sonuç: İmmünsüpresif tedavi öncesi tarama yapılmasına rağmen bazı taramaların eksik yapıldığı tespit edildi. Bu nedenle bu hastaları takip eden hekimlere eğitim verilmesi ve özellikle HBV enfeksiyonu konusunda farkındalık oluşturulmasını önermekteyiz.

Anahtar Kelimeler: İmmünsüpresyon, HBV, HCV, HAV

\section{Abstract}

Background: Screening aimed at hepatitis B reactivation risk is recommended in patients using immunosuppressive drugs. The aim of this study was to investigate the results of hepatitis B virus (HBV), hepatitis $\mathrm{C}$ virus (HCV) and hepatitis A virus (HAV) retrospectively in patients referred to the infectious diseases clinic before immunosuppressive treatment.

Materials and Methods: In our study, 148 patients who were referred to our infectious disease clinic before immunosuppressive therapeutic usage between January 2018-December 2018. Patients files and hospital automation sysytem were analyzed for Hepatitis B surface antigen ( $\mathrm{HBsAg}$ ), hepatitis B surface antibody (Anti$\mathrm{HBs}$ ), hepatitis B core protein antibody (Anti - HBC IgG), anti-hepatitis $C$ virus antibody (Anti-HCV) and antihepatitis A virus antibody (anti -HAV) retrospectively.

Results: HbsAg positivity rate was $4.1 \%$, Anti-HBs positivity rate was $31.8 \%$, Isolated Anti-HBc IgG positivity rate was $1.4 \%$ and Anti-HBs was not detected in two patients. Anti-HCV positivity was detected as $1.4 \%$. Anti-HAV was not examined in $79.7 \%$ of the patients, $12.2 \%$ was determined to have positive Anti-HAV and $8.1 \%$ negative Anti-HAV.

Conclusions: Since some screenings are incomplete despite screening performed for the patients, we recommend that physicians who follow patients receiving immunosuppressive therapy should be trained and raise awareness of HBV infection.

Key words: Immunosuppression, HBV, HCV, HAV.

\section{Sorumlu Yazar I \\ Corresponding Author}

Dr. Mehmet ÇABALAK

Hatay Mustafa Kemal Üniversitesi

Tayfur Ata Sökmen Tıp Fakültesi,

Enfeksiyon Hastalıkları Anabilim

Dalı,

31400 Hatay, Türkiye

Tel: +90 (326) 2291000

(Dahili. 1872),

+90 (536) 9685243

e mail mehcab@yahoo.com

Geliş tarihi / Received:

27.12.2019

Kabul tarihi / Accepted: 10.03.2020

DOI: 10.35440/hutfd.666188 


\section{Giriş}

İmmünsüpresif tedavi alan hepatit B virüs (HBV) enfeksiyonlu hastalar, HBV reaktivasyonu için risk altındadır. Bu reaktivasyon artmış serum aminotransferaz düzeyleri, fulminan hepatik yetmezlik ve ölüm ile sonuçlanabilir (1). Ek olarak immünsüpresif tedavinin kesilmesine ve altta yatan hastalığın tedavisinin gecikmesine yol açabilmektedir. Immünsüpresif tedavi alacak tüm hastalarda tedavi öncesinde hepatit B yüzey antijeni (HBs Ag), hepatit B core protein antikoru (Anti-HBc IgG) değerlendirilmelidir. Hepatit B yüzey antikoru (Anti-HBs) taraması, profilaktik tedaviyi belirlemek için kullanılmadığından anti-HBs'nin HBV reaktivasyonu üzerindeki etkisi tam olarak anlaşılamamıştır (2). İmmünsüpresif tedavi alan kronik HBV hastaları veya HBV ile enfekte kişilerin \%20-50'sinde HBV reaktivasyonu geliştiği çeşitli çalışmalarda bildirilmiştir $(3,4)$. European Association For The Study Of The Liver (EASL), Asian-Pacific For The Study Of The Liver (APASL) ve Centers for Disease Control and Prevention (CDC) HBs Ag prevelansI > $\% 2$ olan ülkelerde immünosüpresif tedavi öncesi mutlaka HBsAg, Anti-HBc IgG ve Anti-HBs taranmasını önermektedirler $(3,5,6)$. HBV enfeksiyonunda diğer serolojik göstergeler olmaksızın Anti-HBc'nin tek başına saptanması izole Anti-HBc pozitifliği olarak adlandırılır. HBV enfeksiyonu ile karşılaşmayı gösterir (7).

Son yıllarda kanser kemoterapisi uygulanan hasta sayılarının artması, organ transplantlarının yaygınlaşması, otoimmün hastalıkların tedavisinde immünsüpresif ilaçların kullanılması ile birlikte immünsüpresif tedavi alan hasta sayısı hızla artmaktadır. Türkiye HBV açısından orta endemisite bölgede yer alması hastaların taranmasını önemli kılmaktadır. Bizim ülkemizde yapılan bazı çalışmalarda hepatit serolojisinin taranması ve takibi konusunda eksiklikler yaşandığı görülmüştür $(8,9)$. Çalışmamızda, kliniğimizde bir yıllık süre içinde immünsüpresif tedavi başlanması planlanan hastalarda, tedavi öncesi tarama sonuçlarının irdelenmesi amaçlandı.

\section{Materyal ve Metod}

Çalışmamız Ocak 2018 - Aralık 2018 tarihleri arasında immünsüpresif tedavi öncesi, Mustafa Kemal Üniversitesi Enfeksiyon hastalıkları kliniğine yönlendirilen 148 hasta dahil edildi. Hastalara ait HBs Ag, Anti-HBs, Anti-HBc IgG, anti hepatit $C$ virüs antikoru (Anti-HCV) ve anti hepatit $A$ virüs antikoru (Anti-HAV) sonuçları hasta dosyalarından ve hastanemiz otomosyon sisteminden retrospektif olarak ulaşıldı. Hbs Ag serolojisi pozitif olgularda hepatit B açısından profilaksi veya tedavi başlanıp başlanmadığı araştıııldı. HBs Ag pozitif ancak alanin aminotransferanz (ALT) ve aspartat aminotransferaz (AST) düzeyleri normal sınırlarda olan HBV DNA'sı negatif olan hastalar HBV taşıycısı olarak kabul edildi. Tarama sırasında Hbs Ag ve Anti-HBc lgG negatif olup Anti-HBs pozitif saptanan hastalar aşılı olarak kabul edildi. Anti-HBc IgG pozitifliği tek başına saptanması izole Anti-HBc lgG pozitifliği olarak kabul edildi. Her üç parametrenin negatif olarak saptanan hastalar, hepatit B ile hiç karşılaşmamış hastalar olarak kabul edildi.

İstatistiksel analizler için IBM SPSS versiyon 21.0 istatistiksel paket programı (SPSS Inc, Chicago, IL, USA) kullanıldı. Değişkenlerin normal dağılıma uygunluğu Kolmogrov-Smirnov testi ve histogram kullanılarak test edildi. Normal dağılıma uymayan değişkenler için ortanca (medyan) ve çeyrekler arası aralık kullanıldı. Gruplar arasında normal dağılıma uymayan numerik değişkenlerin karşılaştırılmasında Mann-Whitney U testi kullanıldı. Çalışma için Hatay Mustafa Kemal Üniversitesi Girişimsel Olmayan Klinik Araştırmalar Etik Kurulundan onay alınmıştır (14.02.2019 tarih, 04 nolu karar).

\section{Bulgular}

Bir yıllık sürede Mustafa Kemal Üniversitesi Sağlık Uygulama ve Araştırma Hastanesi Enfeksiyon Hastalıkları kliniğine immünsüpresif tedavi öncesi yönlendirilen 148 hastada yapılan taramada; Hastaların yaş medyanı 38 yıl (1861,IQR:16) olup, 92'si erkek (\%62.2) ve 56'sı (\%37.8) kadindı.

Tablo 1. Hastaların hepatit göstergelerine göre tarama sonuçları

\begin{tabular}{ll}
\hline Hepatit göstergeleri & $\mathbf{n}=(\%)$ \\
\hline HBsAg & $6(4.1)$ \\
Pozitif & $142(93.9)$ \\
Negatif & $0(0.0)$ \\
Bakılmamış & $47(31.8)$ \\
Anti-HBs & $99(66.9)$ \\
Pozitif & $2(1.4)$ \\
Negatif & $2(1.4)$ \\
Bakılmamış & $12(8)$ \\
Izole Anti-HBc IgG & $18(12.2)$ \\
Pozitif & $12(8.1)$ \\
Bakılmamış & $118(79.7)$ \\
Anti-HAV IgG & \\
Pozitif & $2(1.4)$ \\
Negatif & $145(97.9)$ \\
Bakılmamış & $1(0.7)$ \\
Anti-HCV & Pozitif \\
Negatif & Bakımamış
\end{tabular}

Veriler $n$, (\%) şeklinde sunuldu. HBsAg: hepatit B yüzey antijeni; Anti-HBc lgG: hepatit B kor antikoru; Anti-HCV: hepatit C antikoru; Anti-HAV-IgG: hepatit A antikoru.

Hbs Ag pozitifliği altı hasta (\%4.1), Anti-HBs negatifliği 99 hasta (\%66.9), Anti-HBs pozitifliği 47 hasta (\%31.8) ve iki hastada ise (\%1.4) Anti-HBs bakılmamıştı. Hastaların HBV DNA sonuçlarl; 3053, 153, 128, 36, $76 \mathrm{IU} / \mathrm{ml}$ ve bir hastada negatif idi. HbsAg pozitif hastaların 3 tanesine tenofovir disproksil, 3 tanesine ise entekavir tedavisi başlanmıştı. Anti-HBs pozitif hastalar, Anti-HBs negatif hastalara göre daha genç yaşta olmasına rağmen istatiksel olarak anlamlı bir fark bulunmadı $(p=0.548)$.

İole Anti-HBc IgG pozitifliği saptanmış iki (\%1.4) hasta da HBV DNA negatifti ve bu olgulara 3 ay aralıklarla takip önerilmişti. Hastaların \%8'inde Anti-HBc IgG bakılmamış 
idi.

İki hastada (\%1.4) Anti-HCV pozitifliği tespit edildi fakat her iki hastada da HCV RNA negatif saptandı. Sadece bir hastaya Anti-HCV bakılmadığı tespit edildi. Hastaların yüz on sekizine (\%79.7) Anti-HAV bakılmamış, on sekiz (\%12.2) hastada Anti-HAV pozitif ve on iki (\%8.1) hastada Anti-HAV negatif olarak saptandı. Tablo 1'de hastaların hepatit göstergelerine göre tarama sonuçları özetlenmiştir.

\section{Tartışma}

İmmünsüpresif tedavi alacak kişilerde yaptığımız çalışmada HBs Ag prevalansını \%4.1, Anti -HBs pozitifliği \%31.8, Anti-HBc lgG total pozitifliği \%12.8 olarak saptandı. Türkiye'de normal populasyonda yapılan HBV prevalansı ile ilgili 2009-2010 yılları arasında Tozun ve arkadaşları 5460 hasta taramış, erişkin yaş grubunda $\mathrm{HBsAg} \% 4$, Anti$\mathrm{HBc}$ lgG total pozitifliği \%30.6 ve Anti-HBs pozitifliği \%31.9 oranında saptanmışlar (10). Bizim çalışmamızda Anti-HBC IgG total'in düşük bulunması coğrafi farklılık ve hasta sayısının az olmasına bağıı olabilir. Dağlı ve arkadaşları immünsüpresif tedavi alan Ankilozan Spondilit'li 134 hastada yaptıkları çalışmada HBV prevalansı $\% 4.5$ iken HCV prevalansı \% 1.5 olarak saptamışlar (11).

HBV enfeksiyonunda diğer serolojik göstergeler olmaksızın Anti-HBc'nin tek başına saptanması izole Anti-HBc pozitifliği olarak adlandıılır (7). Dağlı ve arkadaşlarının yaptıkları çalışmada en önemli bulgularından biri 32 hastada (\%23.8) ile izole Anti-HBc IgG pozitiflik oranı saptamışlar bu durum ülke verilerine göre çok yüksek olarak tespit edilmiş (11). İzole Anti-HBc sıklı̆ı çeşitli toplumlarda \%0.1 ile $\% 20$ arasında değişmektedir (12). Ülkemizde yapılan başka bir çalışmada ise polikliniğe başvuran hastalarda bu oranın \%4.7 olduğu gösterilmiştir (13). HBsAg negatif kan bağışçılarında izole Anti-HBc oranları ülkelere göre değişiklikler göstermekte olup ülkemizde bu oran $\% 4.1$ olarak bildirilmiştir (14). Bizim çalışmamızda ise izole Anti-HBC lgG pozitifliğini \%1.4 olarak diğer çalışmalara göre düşük bulundu.

Anti-HBc IgG enfeksiyonunun en güvenilir göstergesi olduğundan HBV ile karşılaşma olup olmadığını ortaya çıkartmak için iyi bir tarama testidir (15). Çalışmamızda Anti-HBc IgG hastaların \%8'ine bakıımamış olması dikkat çekiciydi. Bundan dolayı bu hastaları takip eden hekimler için eğitimler yapılması ve eğitimlerin periyodik olarak tekrar edilmesi gerektiğini önermekteyiz.

Bursa'da yapılan bir çalışmada ise \%2.5 olarak izole AntiHBc pozitifliği saptanırken bu hastalarda HBV DNA pozitifliği \%0.01 olarak saptanmıştır (16). Isparta'da yapılan bir çalışmada ise izole Anti-HBc pozitif olan hastalarda HBV DNA pozitiflik oranı \%6.6 olarak saptanmış (17). Bizim çaışmamızda izole Anti-HBc pozitifliği olan iki hastanın HBV DNA'sı negatif olarak saptandı.

Çalışmamızda akut HBV enfeksiyonu geçiren hasta sap- tanmadı fakat Engin ve ark. yaptıkları çalışmada $445 \mathrm{im}$ münsüpresif tedavi alan hastayı taramışlar ve iki hastada akut HBV enfeksiyonu saptamışlar (18). Bu çalışma immünsüpresif tedavi alan hastalarda hepatit serolojisinin taranmasının önemini bir kez daha ortaya koymaktadır.

Engin ve arkadaşları yaptıkları çalışmada kemoterapi ve biyolojik ajan tedavisi alan hastalarda ideal taranma oranları çok düşük çıkmıştır (18). İdeal olarak taranan hastalarda da profilaksi ya da aşı yönlendirilmelerinin eksik olduğunu saptamışlardır. Bizim çalışmamızda ise taranan hastalarda profilaksi yapıldığı, aşılama önerildiği fakat aşılama sonuçlarının takip edilmediği tespit edildi. Bu nedenle çalışmamızın en önemli kısıtııı̆̆ının retrospektif bir çaIışma olduğu söylenebilir. Ayrıca hastalar tek bir klinik tarafından yönlendirilmesi nedeniyle, kliniklere göre dağılım yapılmamış olması çalışmamızın diğer bir kısıtııık nedenidir.

\section{Sonuç}

Bizim çalışmamızda taranan hastalarda eksik tarama yapıldığı, aşılanmaya yönlendirildiği fakat aşı sonuçlarının kayıt edilmediği anlaşıldı. İmmünsüpresif tedavi başlanan hastaları takip eden hekimlere, hepatit reaktivasyonu gelişmesini önlemek için eğitimler verilmesi ve bu eğitimlerin periyodik olarak tekrar edilmesini önermekteyiz.

\section{Maddi destek ve çıkar iliş̧isi}

Çalışmayı maddi olarak destekleyen kişi/kuruluş yoktur ve yazarların çıkara dayalı bir ilişkisi yoktur.

Etik Kurul: Çalışma için Hatay Mustafa Kemal Üniversitesi Girişimsel Olmayan Klinik Araştırmalar Etik Kurulundan onay alınmıştır (14.02.2019 tarih, 04 nolu karar).

\section{Kaynaklar}

1. Gupta S, Govindarajan S, Fong TL, Redeker AG. Spontaneaus reactivation in chronic hepatitis B: Patterns and naturel history. J Clin Gastroenterol 1990; 12: 562.

2. Hwang JP, Somerfield MR, Alston-Johnson DE, Cryer DR, Feld JJ, Kramer BS, et all. Hepatitis B Virus Screening for Patients with Cancer Before Therapy: American Society of Clinical Oncology Provisional Clinical Opinion Uptodate. J Clin Oncol. 2015; 33(19): 2212.

3. European Association for the Study of the Liver. EASL clinical practice guidelines: Management of chronic Hepatitis B Virus Infection. J Hepatol 2012; 57: 167-85.

4. Türkiye Viral Hepatit Tanı ve Tedavi Rehberi; 2015. (https://www.vhsd.org/tr/turkiye-viral-hepatit-tani-ve-tedavi-rehberi-2-5p)

5. Sarin SK, Kumar M, Abbas Z, Chan HL, Chen CJ, et all. Asian-Pacific clinical practice guidelines on the management of hepatitis B: a 2015 update. Hepatol Int 2016; 10: 1-98.

6. Weinbaum CM, Williams I, Mast EE, Wang SA, Finelli L, Wasley A, et all. Centers for Disease Control and Prevention (CDC). Recommendations for identification and public health management of persons with chronic hepatitis B virus infection. MMWR Recomm Rep 2008; 57: 1-20. 7. Ertekin V, Selimoğlu MA, Alp H. Erzurumda 6-17 yaş grubu çocuklarda HBV enfeksiyonu prevalansı çalışması sırasında saptanan atipik serolojik profiller. Viral Hepatit Derg 2003; 1: 60-3.

8. Ramirez J, Duddempudi AT, Sana MM, Hasan SS, de Los Santos M, 
Song J, et al. Screening for hepatitis B in patients with lymphoma. Proc (Bayl Univ Med Cent) 2015; $28:$ 438-42.

9. Day FL, Link E, Thursky K, Rischin D. Current hepatitis B screening practices and clinical experience of reactivation in patients undergoing chemotherapy for solid tumors: a nationwide survey of medical oncologists. J Oncol Pract 2011;7:141-7.

10. Tozun N, Ozdoğan O, Cakaloglu Y, Idilman R, Karasu Z, Aakarca $U$, et all. Seroprevalance of hepatitis $B$ and $C$ virus infections and risk factors in Turkey: a fieldwork TURHEP study. Clin Microbiol Infect 2015;21:1020-6.

11. Dağlı Ö. Kasapoğlu Aksoy M. Ankilozan spondilitli hastalarda hepatit $B$ ve hepatit C enfeksiyon prevalansı. Ortadoğu Tıp Derg 2018;10(3):297-301

12. Sünbül M, Eroğlu $C$, Barut Ş, Esen Ş, Hökelek M, Leblebicioğlu $H$. HBsAg ve anti-HBs negatif, anti-HBc pozitif olgularda hepatit $B$ aşısına yanit. Viral Hepatit Derg 1999;1:34-6.

13. Altunay H, Kenar S, Koçak N, Çavuşlu Ş. İzole anti-HBc pozitifliğinde hepatit $B$ virüs enfeksiyözitesinin araştıııması. Viral Hepatit Derg 2003:8:10-5.

14. Gurol E, Saban C, Oral O, Cigdem A, Armagan A. Trends in hepatitis $B$ and hepatitis $C$ virus among blood donors over 16 years in Turkey. Eur J Epidemiol 2006;21:299-305.

15. Aygen B, Demir AM, Gümüş M, Karabay O, Kaymakoğlu S, Köksal AŞ, et all. Immunosuppressive therapy and the risk of hepatitis $B$ reactivation: Consensus report. Turk J Gastroenterol 2018;29(3):259-69.

16. Bal SH, Heper Y, Kumaş LT, Mıstık R, Töre O. İzole anti-HBc pozitif olgularda HBV-DNA varı̆̆ının araştıııması ve bu olguların kan bankacllığı açısından önemi. Mikrobiyol Bul 2009;43:243-50.

17. Tas T, Kaya S, Onal $S$, Küçükbayrak $A$. The detection of HBV-DNA with polymerase chain reaction in blood donors with isolated hepatitis $B$ core antibody. Med Glass (Zenica) 2012; 9: 227-30.

18. Engin B, Günay S, Binicier ÖB, Hakim GD, Yıldız C, Paköz ZB. İmmünsüpresif hastalarda hepatit $B$ virüs tarama sıklığı ve gerçek yaşam verileri. FNG \& Bilim Tıp Dergisi 2016;2(4):256-259 